\title{
Designed to Succeed: Participatory Governance, Transaction Cost, and Policy Performance*
}

\author{
Jongkon Lee**
}

\begin{abstract}
This article examines the effect of participatory governance on policy performance in the United States, which is shaped by external and internal factors related to transaction cost. Externally, if transaction-cost-related policy conditions are uncertain - thereby increasing transaction cost - the effect of participatory governance on policy performance is less positive. Internally, noninstitutionalized participatory governance methods (e.g., public meetings) are less effective than institutionalized ones in improving policy performance (e.g., advisory committees). In addition, these internal and external factors affect the choice of participatory governance methods by government agencies: agencies are more likely to employ institutionalized participatory governance methods under low-transaction-cost policy conditions.
\end{abstract}

Keywords: participatory governance, transaction cost, policy performance

\section{INTRODUCTION}

For several decades, participatory governance arguments have been prevalent in public administration studies (Ansell \& Gash, 2008). Participatory governance is defined as "the institutional arrangements that allow the public to take part in deliberation, negotiation, and administrative decision making about public affairs" (Andersson and van Laerhoven, 2007). In this article, the concept is related to collaboration between agencies and nonstate policy stakeholders in the policy making stage rather than to coproduction with social actors in the implementation stage. Because scientific and

\footnotetext{
* This work was supported by the National Research Foundation of Korea Grant funded by the Korean Government (NRF-2014S1A5A8016935).

** Jongkon Lee is an assistant professor in the Department of Political Science and International Relations at Ewha Womans University. E-mail: jongkonlee@ewha.ac.kr.
}

Manuscript received May 9, 2016; out for review May 31, 2016; review completed July 10, 2016; accepted July 18, 2016.

The Korean Journal of Policy Studies, Vol. 31, No. 2 (2016), pp. 1-22.

(C) 2016 by the GSPA, Seoul National University 
time and place information is an important resource in making public policies, collaborative efforts to accumulate policy information is critical for effective administration (Imperial, 2005; Eom \& Bae, 2014). In addition, close interactions with social policy stakeholders make agencies more responsive (Leach, 2006) and maximize informational benefits (Sousa \& Klyza, 2007). Many studies on participatory governance have accentuated the positive effects of such interactions on policy performance (Paletta, 2012). For example, Neshkova \& Guo (2012) illustrate that U.S. state transportation agencies could acquire detailed site-specific information through participatory governance, thereby improving policy performance. Likewise, Nicholson-Crotty \& O'Toole (2004) show that U.S. municipal police departments could gain a better understanding of policy environments (e.g., arrest rates) through participatory governance and so enhance their policy performance.

Participatory governance is not a panacea that uniformly improves policy performance in all conditions (Doberstein, 2016; Gerlak, Heikkila, \& Lubell, 2012; Choi, 2014). Rather, the effect of participatory governance may vary depending on policy conditions or participation methods (Frieling, Lindenberg, \& Stokman., 2014; Robertson \& Choi, 2012). For example, participatory governance is considered to be especially successful in the U.S. Environmental Protection Agency (EPA) (Gerlak et al., 2012), and several studies have argued that its participatory governance efforts such as negotiated rulemaking enhance the flow of information, thereby promoting policy performance (e.g., Lubell, 2000). However, evaluations of the agency's policy performance have not always been positive. Several other studies claim that several EPA participatory governance programs such as Project XL have failed to improve policy performance (e.g., Marcus, Geffen, \& Sexton, 2002). In addition, according to the Program Assessment Rating Tool (PART) developed by the Office of Management and Budget during the George W. Bush presidency to measure policy performance, no environmental program implemented by EPA was evaluated as "Effective."

These inconsistent study results imply that participatory governance may not be linearly related to policy performance. In this article, I propose that the relative benefits of participatory governance vary depending on internal and external factors that are related to the transaction cost incurred during the interaction between agencies and social policy stakeholders. I run several regression tests that indicate that uncertain policy conditions that increase the transaction cost limit the positive effect of participatory governance on policy performance and that the positive effect is robust only when institutionalized participatory governance methods are used. 


\section{THEORY AND HYPOTHESES: PARTICIPATORY GOVERNANCE AND TRANSACTION COST}

According to Williamson (1985), efficient forms of governance can be determined by transaction cost. In particular, transaction cost economics (TCE) studies have argued that participatory governance is more appropriate for low transaction costs, whereas hierarchical governance structures are appropriate for high transaction costs (Williamson, 1991, 1996). Therefore, a participatory system is not efficient if the cost of transactions with stakeholders is high.

Transaction cost analysis has been applied extensively to government contracting in the policy implementation stage, particularly to alternative service production arrangements such as internal production, partnerships, contracting out, subsidies, and franchises (Tang \& Mazmanian, 2010). For example, Brown and Potoski (2003) argue that government contracting mechanisms are likely to be determined by transaction cost. Likewise, Reeves (2008) analyzes the practice of contracting in public-private partnerships in terms of transaction cost. However, transaction cost has not been sufficiently examined in terms of stakeholder participation in agency policy making. Rather, many recent public administration studies in support of participatory governance have generally assumed that participatory governance in the policy making stage (e.g., in advisory committees, negotiated rulemakings, and dispute resolution processes) is almost always positive without sufficiently examining transaction cost environments. In this vein, myriad studies have emphasized participatory policy making as a response to adversarial administration (Singleton, 2002; Innes \& Booher, 1999; Freeman, 1997; Wondolleck \& Yaffee, 2000; Gunningham, 2009; Kelly, 2004) and have argued that dialogues beyond organizational boundaries are necessary to resolve conflicts and perform efficiently (Harter, 1982; Harmon, 1995; Roberts, 2002). Mee (1997), for instance, shows that the EPA's engaging in regulatory negotiations generated cooperation among stakeholders and resolved rulemaking stalemates in the combined sewer outflows regulation. In other words, participatory governance studies have generally applauded open structures within agencies and public participation without serious consideration of transaction cost.

Nevertheless, diverse transaction problems can arise when nonstate stakeholders take part during the policy making stage, undermining policy performance (Ansell, 2011). Individual nonstate policy stakeholders have their own policy preferences that may conflict with others' goals. Thus, they frequently provide biased information and interrupt policy making processes, thereby inevitably increasing transaction cost. Even though the participatory governance methods used by the EPA, for instance, have generally been beneficial (Langbein \& Kerwin, 2000), they have at times caused 
significant inefficiency, in particular when the interests of nonstate stakeholders have conflicted, thereby increasing transaction cost. In an environmental dispute resolution conference, EPA administrator William Ruckelshaus said that more than $80 \%$ of the EPA's rules had been challenged and that these judicial challenges seriously compromised policy performance (Susskind \& McMahon, 1985).

Likewise, significant oversight on the part of elected officials that can easily affect agency decisions also increases transaction cost by promoting uncertainty in administration (Lee, 2013). For example, in the early 1980s, the U.S. Federal Communications Commission (FCC) initiated a process to amend the 7-7-7 rule, which had been enacted in 1953, under which a media organization could own up to seven television stations, seven FM radio stations, and seven AM radio stations. However, severe congressional oversight delayed the FCC's rulemaking, and nonstate policy stakeholders lost trust in agency proposals and became reluctant to express their opinions and ideas. Consequently, it took several years for FCC to amend the rule, undermining the policy performance of the agency.

Traditional participatory governance studies do not completely ignore transaction cost. Rather, they assert that "fruitful conflict" between agencies and nonstate stakeholders will result in collaboration, thereby advancing understanding between different interests (Ansell, 2011). Nevertheless, these studies do not sufficiently discuss or empirically examine what makes "fruitful conflict" possible and what is impact is on transaction cost. This study posits several hypotheses based on TCE and participatory governance arguments. First, as a number of participatory governance studies have pointed out, participatory governance tends to have positive effects on policy performance. However, externally, the effect of participatory governance on policy performance will vary depending on transaction-cost-related policy conditions. Uncertain environmental and behavioral conditions that lead to higher transaction costs will limit the positive effect of participatory governance. Internally, the institutional embeddedness of interactive relationships improves the mutual trust between agencies and social policy stakeholders, thereby limiting the negative effect of transaction costs (Warner, 2006; Willem \& Lucidarme, 2014). Thus, the effect of noninstitutionalized participatory governance on policy performance might be less positive than that of institutionalized participatory governance even under low-transaction-cost policy conditions.

In addition, if internal and external factors determine the effect of participatory governance, agencies could manage their own participatory governance methods by considering these factors. TCE studies have argued that rational actors would determine their form of governance in accordance with transaction costs. Thus, if agencies are neutrally rational decision makers, they would be more likely to devote more resources to institutionalized participatory governance methods such as advisory committees 
under low-transaction-cost policy conditions. And because the effect of noninstitutionalized participatory governance methods such as public meetings might be vulnerable even under low-transaction-cost policy conditions, agencies would have less incentive to consider using those methods. Moreover, as Moe (1990) points out, not only transaction cost but also political environments affect agencies' governance designs. In particular, the effect of political environments is greater for noninstitutionalized participatory governance methods because institutionalization insulates policy from politics, which makes it difficult for outside actors to affect them (Chubb \& Peterson, 1985). In sum, transaction-cost-related policy conditions rather than political environments might be more meaningful for institutionalized participatory governance. In contrast, political environments rather than transaction-cost-related policy conditions may be more significant in determining which noninstitutionalized participatory governance methods are used.

\section{HYPOTHESIS TESTING AND DISCUSSION: THE EFFECT OF PARTICIPATORY GOVERNANCE}

For statistical evaluation of the hypotheses, data on 27 U.S. federal regulatory agencies were used for regression tests (see appendix 1). To make the samples uniform and prevent possible biases from agency-specific characteristics, only the largest domestic regulatory federal agencies (i.e., the agencies that have more than one thousand employees and more than three hundred Code of Federal Regulations $[C F R]$ pages in the 2000s) were included in the dataset. Large agencies enjoy the positive effects of economy of scale, and average policy performance can be affected by the type of policy in place.

\section{Variables and Measurements}

\section{Policy Performance}

There have been several attempts to measure policy performance in the United States, despite the fact that making such assessments is difficult owing to the highly heterogeneous nature of agency operations. For example, the Merit Principles Survey (MPS) performed by the U.S. Merit Systems Protection Board covers a variety of performance issues including work environment, employee knowledge, and advisory services. Several studies have used MPS to measure organizational performance in U.S. federal agencies (e.g., Brewer \& Selden, 2000). However, the MPS measures are 
based on self-assessment. Therefore they are inevitably biased, and the neutrality problem is significant (Meier \& O'Toole, 2013). The Federal Performance Project (FPP) conducted in the later 1990s and early 2000s evaluated policy performances of U.S. federal agencies in a more neutral manner, based on several criteria such as managers' use of agency resources and maintenance of physical infrastructures and how well they communicate. However, the applicability of the measure was limited; only 27 agencies' performances were measured in 1999, 2000, and 2001.

In comparison with MPS and FPP, PART is less problematic. The instrument consisted of four categories: program purpose and design, strategic planning, program management, and program results. Individual programs were given a numerical score that aligned with a categorical scale of performance ranging from effective (85-100), moderately effective (70-84), adequate (50-69) to ineffective (0-49). Many administrative programs were evaluated with PART in an effort on the part of the Bush admiration to promote it. Thus, many administrative studies likewise adopted PART as a measure of policy performance (e.g., Gallo \& Lewis, 2012). Several studies have considered the question of the neutrality of the measure, concluding that it tended to be highly neutral (e.g., Moynihan, 2013; Dull, 2006), and so in this study, I have used average PART evaluations of individual agencies as the measure of policy performance. The data were derived from ExpectMore.gov.

\section{Participatory Governance}

As defined in the introduction section, the inclusion of nonstate policy stakeholders in the policy making stage is a core part of participatory governance. In the United States, there are two main tools of participatory governance: advisory committees and public meetings. ${ }^{1}$ Historically, the advisory committee is a dominant participatory governance method among US federal agencies. ${ }^{2}$ There are more than 1,000 advisory

1. Admittedly, there are other nonstate stakeholders participation methods such as the ombudsman and negotiated rulemaking. However, although negotiated rulemaking was historically one of the most important methods U.S. federal agencies in improving nonstate stakeholders' participation, only few agencies have used the method since the mid1990s (Coglianese, 1997; Lubbers, 2008). Ombudsmen have been used by many U.S. federal agencies and continue to be widely used todays, but they cannot overturn a federal agency's decision or delay its implementation, and, in reality, they have played no more than a symbolic role (Shapiro, 2007).

2. In this study, I have considered all types of advisory committees regardless of level of authority and committee functions, because advisory committees in general promote collaboration with nonstate stakeholders. However, I excluded advisory committees that have never convened 
committees operated by US federal agencies currently. The qualities of individual advisory committees tend to be consistent because the Federal Advisory Committee Act (P.L. 92-463, FACA) provides broad guidelines for committee management. For example, the act requires that all federal advisory committees be "fairly balanced in terms of the points of view represented and the functions to be performed." Through advisory committees, social policy stakeholders come up with creative solutions to problems by negotiating regulations and adjusting agency proposals in transparent meetings (Bingham, 2010; Applegate, 1998; Balla, 2004). In the 1980s, the Federal Aviation Administration (FAA), for example, suffered from serious conflicts and found itself in a rulemaking stalemate in regulating flight times, duty time, and rest period for flight crewmembers. The FAA established the Regulatory Negotiation Advisory Committee to tackle these administrative problems and was successful in resolving them (Gormley \& Balla, 2004). Because PART data are cross-sectional during the George W. Bush administration, this study uses the average advisory committee spending (during FY2001-FY2008) divided by the average budget authority in order to neutralize the effect of agency size. All budget and spending data were revised to be constant in 2008 dollars.

The public meeting is also a popular participatory governance method (Adams, 2004; Wang \& Wart, 2007). However, advisory committees are likely to last for several years without significant member changes, and thus are highly institutionalized in policy communities, whereas the relationship between agencies and social policy stakeholders in public meetings is instant and temporary. Even though this characteristic of public meetings helps keep management costs down, they are not well institutionalized (McComas, 2001). Thus, it can be inferred that the effect of public meetings may be limited under high-transaction-cost policy conditions compared with advisory committees. In measuring this variable, I included public hearings, workshops, and open houses given that the all these types of meetings are open to the public. ${ }^{3}$ However, I excluded simple informational meetings because these are intended only to provide administrative

or that are not active, because inactive advisory committees are meaningless as participatory governance. Because agencies tend to employ different types of advisory committees, excluding some types of advisory committees can underestimate the variable. For example, while the Nuclear Regulatory Commission tends to use scientific technical program advisory boards, the Small Business Administration has generally used national policy issues advisory boards.

3. Individual agencies tend to depend on different types of public meetings. For example, the Minerals Management Service has generally employed public hearings, while the Forest Service relies on open houses. Thus, excluding specific types of public meetings could underestimate the frequency of public meetings in specific agencies. 
information to the public rather than promote participation. To avoid the biased effect of agency size, the number of public meetings was divided by budget authority (in 2008 billion dollars).

\section{Transaction-Cost-Related Policy Conditions}

Transaction cost is highly contingent on environmental conditions and participant behaviors (Williamson, 1996), and so it will tend to increase in environmentally and behaviorally uncertain policy conditions (John \& Weitz, 1988; Rangan, Corey, \& Cespedes, 1993). ${ }^{4}$ Environmental uncertainty refers to the changeability and complexity of policy environments. When elected officials are able to easily overturn agency decisions or when policy issues are too complex to be comprehensively understood, the interactions between agencies and social policy stakeholders may become uncertain, thereby increasing transaction cost. To measure environmental uncertainty, this study used the number of congressional hearings in which individual federal agencies participated and the number of Government Accountability Office (GAO) reports on specific agencies as witnesses. These measures generally imply changeable and complex policy environments (Wolfe, 2012). Congressional hearings and GAO investigations into agencies' activities increase the possibility that agency decisions may be reversed by elected officials (Cameron \& Rosendorff, 1993), thereby providing new opportunities for social policy stakeholders to engage in policy making or threatening the contributions they have already made (Paulson, 2004). Congressional hearings and GAO investigations are costly for legislators, and so they are reluctant to use these them (Epstein \& O'Halloran, 1999). Thus, frequent congressional oversight generally indicates that legislators have a high incentive to overturn agency decisions (Aberbach, 1990; Jones et al., 2014). Policy stakeholders cannot have sufficient trust in agency proposals if these proposals are hounded by congressional hearings or GAO investigations. These measures also reflect the complexity of policy environments. Legislators tend to hold congressional hearings or ask GAO to investigate agency decisions regarding highly complex issues (Epstein \& O'Halloran, 1999). In this regard, these two measures can represent environmental uncertainty as transaction-cost-related policy conditions.

4. Theoretically, Oliver Williamson emphasizes not only uncertainty but also asset specificity. In this article, however, asset specificity that refers to sunk costs that have little value outside of specific transactions are not measured as a transaction-cost-related policy condition, since environmental uncertainty is an antecedent of asset specificity, and these two are correlated and sequential rather than independent (Rangan et al., 1993). 
Behavioral uncertainty refers to the uncertainty related to the risk of participant opportunism (Williamson, 1985). If policy demands are heterogeneous, conflicts are more likely among social policy stakeholders, which may make them more likely to provide agencies with biased information (Osborne et al., 2000; Pizzo, 2013). Thus, competitive participation among multiple social policy stakeholders inflates transaction cost (Robertson \& Choi, 2012; Lee, 2013). Lobbying in particular has a significant impact on transaction cost during the policy enactment stage (e.g., McCann, Colby, Easter, Kasterine, \& Kuperan, 2005). Because interest group lobbies represent heterogeneous policy demands in agency policy making, this study used the frequency of lobbies on individual agencies as a measure for behavioral uncertainty. For the measure, the data of the Center for Responsive Politics were used, although owing to the database's limitations, the frequency of lobbies for 5 out of the selected 27 agencies (Agricultural Marketing Service, Animal and Plant Health Inspection Service, Food and Nutrition Service, Farm Service Agency, and Food Safety and Inspection Service) could not be measured. In addition, the heterogeneity of policy demands and competitive participation tend to increase as policy issues become salient (Haider-Markel \& Meier, 1996; Gormley, 1986). Thus, for issue salience, the number of New York Times articles that cite agency behaviors was also measured.

\section{Other Variables}

Several other variables such as budgetary authority and a dummy variable of independent agencies were also included in this study as controls. Budgetary authority indicates the authority provided by law to a federal agency to spend money for certain purposes. This variable was inserted to control for the effect from economy of scale. Likewise, independent agencies tend to be more autonomous than nonindependent ones in making public policies, which may affect policy performance. In addition, if policy issues are highly salient, agencies are more likely to feel pressure to enhance policy performance. The size of the budget authority was revised to be constant in billions of 2008 dollars to adjust for inflation. In addition, the average values of variables between FY2001 and FY2008 were generally used.

\section{Regression Test 1: \\ Transaction Cost and the Effect of Participatory Governance}

Because this study selected only 27 U.S. federal agencies to make the samples uniform, a small sample size problem is possible. To prevent this problem, I check the normality of the dependent variable and use multiple regression models to reduce the 
Table 1. Descriptive Statistics

\begin{tabular}{l|l|r|r|r}
\hline \multicolumn{1}{c|}{ Variables } & \multicolumn{1}{c|}{ Measures } & Mean & \multicolumn{1}{c|}{ SD } & \multicolumn{1}{c}{ Max. } \\
\hline policy performance & PART & 69.73 & 8.51 & 90.29 \\
\hline \multirow{2}{*}{ participatory governance } & advisory committee spending & 0.05 & 0.12 & .576 \\
\cline { 2 - 5 } & public meeting & 40.86 & 159.54 & 832.31 \\
\hline \multirow{4}{*}{$\begin{array}{l}\text { transaction-cost-related } \\
\text { policy conditions }\end{array}$} & lobbying & 134.59 & 171.88 & 715 \\
\cline { 2 - 5 } & issue salience & 130.45 & 243.61 & 1102.13 \\
\cline { 2 - 5 } & hearings & 4.78 & 4.51 & 16.5 \\
\cline { 2 - 5 } & GAO investigations & 5.73 & 8.14 & 43.625 \\
\hline
\end{tabular}

number of independent variables. Even when the sample size is small, if the data of the dependent variable is normally distributed, the sample means of the variable should also be normally distributed, thereby limiting the small sample size problem. The normality of the dependent variable (i.e., PART for policy performance) is demonstrated by Shapiro-Wilk W test $\left(\mathrm{W}=.964, \mathrm{z}=.106, \mathrm{p}\right.$-value=.458) and Shapiro-Francia $\mathrm{W}^{\prime}$ test $\left(\mathrm{W}^{\prime}=.959, \mathrm{z}=.539\right.$, $\mathrm{p}$-value=.295), in which $\mathrm{p}$-value $>.05$ indicates normal distribution. In addition, in order to reduce the number of independent variables, I have run multiple models depending on the different measures of transaction-cost-related policy conditions (i.e., lobbying, issue salience, hearings, and GAO investigations).

Tables 2 and 3 show the regression test results on the effects of advisory committees and public meetings on policy performance. Both tables generally support the hypotheses that participatory governance tends to have positive effects on policy performance and that uncertain environmental and behavioral conditions yield higher transaction costs that limit the positive effect of participatory governance. Table 2 indicates that more advisory committee spending promoted policy performance. However, the coefficients of the interactive variables between transaction-cost-related policy conditions and advisory committee spending are negative, which implies that the effect of participatory governance decreases as transaction cost increases. For all measures of transactioncost-related policy conditions (i.e., lobbying, issue salience, hearings, and GAO investigations), the statistical results are consistent. Likewise, table 3 shows that the effect directions of public meetings are similar to those of advisory committees, even though the negative effects of the two interactive variables (in terms of issue salience and hearings) are not statistically significant. In other words, similar to advisory committees, the positive effect of public meetings on policy performance tends to decrease as transaction cost increases.

In addition, the hypothesis that that the positive effect of institutionalized participa- 
Table 2. Effect of Advisory Committee Spending on Policy Performance

\begin{tabular}{|c|c|c|c|c|}
\hline \multirow{2}{*}{ Dependent Variable } & \multicolumn{4}{|c|}{ Policy Performance } \\
\hline & model 1-1 & model 1-2 & model 1-3 & model 1-4 \\
\hline advisory committee spending & $\begin{array}{r}50.448^{*} \\
(24.516)\end{array}$ & $\begin{array}{r}34.572^{\dagger} \\
(24.213)\end{array}$ & $\begin{array}{r}65.578^{\dagger} \\
(41.650)\end{array}$ & $\begin{array}{l}38.713^{*} \\
(21.537)\end{array}$ \\
\hline $\begin{array}{l}\text { lobbying }(\text { mean }=134.59) \\
\times \text { advisory committee spending }\end{array}$ & $\begin{array}{l}-.106^{\star \star} \\
(.036)\end{array}$ & & & \\
\hline $\begin{array}{l}\text { issue salience }(\text { mean }=130.45) \\
\times \text { advisory committee spending }\end{array}$ & & $\begin{array}{l}-.132^{*} \\
(.060)\end{array}$ & & \\
\hline $\begin{array}{l}\text { hearings }(\text { mean }=4.78) \\
\times \text { advisory committee spending }\end{array}$ & & & $\begin{array}{l}-5.324^{*} \\
(2.703)\end{array}$ & \\
\hline $\begin{array}{l}\text { GAO investigations }(\text { mean }=5.73) \\
\times \text { advisory committee spending }\end{array}$ & & & & $\begin{array}{l}-1.442^{* *} \\
(.004)\end{array}$ \\
\hline issue salience & $\begin{array}{l}.019^{\star \star \star} \\
(.004)\end{array}$ & $\begin{array}{l}.008 \\
(.006)\end{array}$ & $\begin{array}{l}.015^{\star \star \star} \\
(.004)\end{array}$ & $\begin{array}{l}.017^{* * *} \\
(.004)\end{array}$ \\
\hline independent agency & $\begin{array}{r}7.200^{+} \\
(4.404)\end{array}$ & $\begin{array}{r}6.310^{+} \\
(4.437)\end{array}$ & $\begin{array}{r}6.943^{+} \\
(4.302)\end{array}$ & $\begin{array}{r}6.620^{+} \\
(4.378)\end{array}$ \\
\hline budget authority & $\begin{array}{l}.013^{\star \star} \\
(.005)\end{array}$ & $\begin{array}{l}.012^{* *} \\
(.005)\end{array}$ & $\begin{array}{l}.013^{\star \star} \\
(.004)\end{array}$ & $\begin{array}{l}.013^{* *} \\
(.004)\end{array}$ \\
\hline constant & $\begin{array}{l}63.585^{\star \star \star} \\
(2.18)\end{array}$ & $\begin{array}{l}65.376^{\star \star \star} \\
(1.694)\end{array}$ & $\begin{array}{l}64.446^{\star \star \star} \\
(1.699)\end{array}$ & $\begin{array}{l}64.499^{* * *} \\
(1.696)\end{array}$ \\
\hline prob $>F$ & .0000 & .0000 & .0000 & .0000 \\
\hline$R^{2}$ & .526 & .460 & .486 & .485 \\
\hline $\mathrm{N}$ & 22 & 27 & 27 & 27 \\
\hline
\end{tabular}

Robust standard errors are in parentheses. ${ }^{\dagger}$ significant at .10 level, ${ }^{*}$ significant at .05 level, ${ }^{* *}$ significant at .01 level, ${ }^{* * *}$ significant at .001 level (one-tailed).

tory governance is more robust than that of noninstitutionalized participatory governance is also supported by comparing tables 2 and 3. Given the average values of four different transaction-cost-related policy conditions (see table 1), the effect of advisory committee spending was highly positive. Given the average values of lobbying, issue salience, hearings, and GAO investigations, the coefficients of advisory committee spending are $36.18,17.35,40.13$, and 30.45 , which implies that advisory committees are almost always meaningful in promoting policy performance, even though their effects decrease depending on transaction-cost-related policy conditions. In contrast, public meetings may negatively affect policy performance even under low-transactioncost policy conditions. Given the average values of lobbying and GAO investigations, the coefficients of the public meeting becomes negative; -.016 and -.005 for lobby and 
Table 3. Effect of the Public Meeting on Policy Performance

\begin{tabular}{|c|c|c|c|c|}
\hline \multirow{2}{*}{ Dependent Variable } & \multicolumn{4}{|c|}{ Policy Performance } \\
\hline & model 2-1 & model 2-2 & model 2-3 & model 2-4 \\
\hline public meeting & $\begin{array}{l}.038^{* \star *} \\
(.009)\end{array}$ & $\begin{array}{l}.031^{* *} \\
(.009)\end{array}$ & $\begin{array}{l}.050^{\dagger} \\
(.035)\end{array}$ & $\begin{array}{l}.058^{\star \star \star} \\
(.006)\end{array}$ \\
\hline $\begin{array}{l}\text { lobbying }(\text { mean }=134.59) \\
\times \text { public meeting }\end{array}$ & $\begin{array}{l}-.0004^{+} \\
(.000)\end{array}$ & & & \\
\hline $\begin{array}{l}\text { issue salience }(\text { mean }=130.45) \\
\times \text { public meeting }\end{array}$ & & $\begin{array}{l}-.000 \\
(.000)\end{array}$ & & \\
\hline $\begin{array}{l}\text { hearings }(\text { mean }=4.78) \\
\times \text { public meeting }\end{array}$ & & & $\begin{array}{l}-.009 \\
(.012)\end{array}$ & \\
\hline $\begin{array}{l}\text { GAO investigations }(\text { mean }=5.73) \\
\times \text { public meeting }\end{array}$ & & & & $\begin{array}{l}-.011^{* * *} \\
(.002)\end{array}$ \\
\hline issue salience & $\begin{array}{l}.019^{* \star *} \\
(.004)\end{array}$ & $\begin{array}{l}.017^{\star \star \star} \\
(.032)\end{array}$ & $\begin{array}{l}.016^{* \star *} \\
(.004)\end{array}$ & $\begin{array}{l}.016^{\star \star \star} \\
(.003)\end{array}$ \\
\hline independent agency & $\begin{array}{c}1.215 \\
(3.054)\end{array}$ & $\begin{array}{l}1.010 \\
(3.376)\end{array}$ & $\begin{array}{c}1.723 \\
(2.508)\end{array}$ & $\begin{array}{l}2.994 \\
(2.294)\end{array}$ \\
\hline budget authority & $\begin{array}{l}.014^{* * *} \\
(.003)\end{array}$ & $\begin{array}{l}.015^{\star \star \star} \\
(.003)\end{array}$ & $\begin{array}{l}.014^{* \star *} \\
(.003)\end{array}$ & $\begin{array}{l}.013^{\star \star \star} \\
(.003)\end{array}$ \\
\hline constant & $\begin{array}{l}65.527^{* * *} \\
(2.281)\end{array}$ & $\begin{array}{l}65.380^{* * *} \\
(1.751)\end{array}$ & $\begin{array}{l}65.638^{* * *} \\
(1.856)\end{array}$ & $\begin{array}{l}65.614^{* * *} \\
(1.761)\end{array}$ \\
\hline prob $>F$ & .0000 & .0000 & .0000 & .0000 \\
\hline$R^{2}$ & .581 & .535 & .567 & .582 \\
\hline $\mathrm{N}$ & 22 & 27 & 27 & 27 \\
\hline
\end{tabular}

Robust standard errors are in parentheses. ${ }^{\dagger}$ significant at .10 level, ${ }^{*}$ significant at .05 level, ${ }^{* *}$ significant at .01 level, ${ }^{* *}$ significant at .001 level (one-tailed).

GAO investigations. From the contrasting regression results, it can be inferred that the public meeting as a noninstitutionalized participatory governance method is ineffective even under low-transaction-cost policy conditions.

\section{Regression Test 2: Management of Participatory Governance}

In testing the hypothesis that transaction-cost-related policy conditions rather than political environments might be more meaningful for institutionalized participatory governance and that political environments rather than transaction-cost-related policy conditions may be more significant in determining which noninstitutionalized participatory governance methods are used, I have used advisory committee spending (measured 
in 2008 thousand dollars) and the numbers of public meetings as dependent variables. For the dependent variables, I collected the annual data for the selected agencies over the eight years of the George W. Bush presidency (i.e., FY2001-FY2008) and ran panel regressions. To prevent autocorrelation and heteroskedasticity problems that are generally derived from panel regressions, fixed effects regressions with $\mathrm{AR}(1)$ disturbances were employed.

For independent variables, four transaction-cost-related policy conditions (i.e., lobby, issue salience, hearings, and GAO investigations) have been included as well as several political environment variables - executive-legislative conflict, unified government, and a liberalism score. When the political environment is favorable for agencies, they can acquire sufficient procedural justice through participatory governance without political risks. But when the political environment is unfavorable, agencies could end up providing their political opponents with the opportunity to criticize and overturn agency decisions. Therefore, agencies are more likely to employ participatory governance methods when the political environment are favorable - that is, when ideological conflict between the executive and legislative branch is minimal or when the public generally supports agency decisions ideologically. To measure the extent of executivelegislative conflict, the ideological difference between President Bush and the median number of members of U.S. Congress was calculated based on the first-dimension DW-NOMINATE scores. ${ }^{5}$ For convenience, this measure was multiplied by a thousand. Likewise, agencies are more likely to use participatory governance methods in the context of a unified government, and so a dummy variable of unified government has been inserted into regression models. Similarly, when the public mood is ideologically supportive of the president, agencies will be more open to social policy stakeholders. For this variable, the public policy mood, a time-series measure of the liberalism level of the public developed by James A. Stimson, has been used. ${ }^{6}$

The amount of agency resources and the extent of regulation can also affect the availability of participatory governance methods. Therefore, budget authority (in 2008 billion dollars) and the number of CFR pages that represent the number of regulations an agency has have been included as controls. In addition, a dummy variable of independent agencies is also included, because independent agencies can manage participatory governance methods more autonomously.

5. The DW-NOMINATE score, developed and measured by several scholars such as Keith Poole, Howard Rosenthal, and Nolan McCarty, is the most widely used measure for the political ideologies of elected officials. The data of DW-NOMINATE come from voteview. com.

6. The data pertaining to public policy mood come from http://stimson.web.unc.edu/data. 
Table 4. Factors Affecting the Management of Participatory Governance Methods

\begin{tabular}{|c|c|c|c|c|c|c|}
\hline \multirow{2}{*}{ Dependent Variables } & \multicolumn{3}{|c|}{ Advisory Committee Spending } & \multicolumn{3}{|c|}{ Public Meeting } \\
\hline & Model 3-1 & Model 3-2 & Model 3-3 & Model 4-1 & Model 4-2 & Model 4-3 \\
\hline lobbying & $\begin{array}{l}-.656^{*} \\
(.403)\end{array}$ & $\begin{array}{l}-.673^{\dagger} \\
(.410)\end{array}$ & $\begin{array}{l}-.655^{\dagger} \\
(.406)\end{array}$ & $\begin{array}{l}-.061 \\
(.050)\end{array}$ & $\begin{array}{l}-.045 \\
(.050)\end{array}$ & $\begin{array}{l}-.053 \\
(.049)\end{array}$ \\
\hline issue salience & $\begin{array}{l}-.268^{*} \\
(.156)\end{array}$ & $\begin{array}{l}-.261^{\dagger} \\
(.158)\end{array}$ & $\begin{array}{l}-.264^{*} \\
(.159)\end{array}$ & $\begin{array}{l}.003 \\
(.018)\end{array}$ & $\begin{array}{l}-.007 \\
(.018)\end{array}$ & $\begin{array}{l}-.008 \\
(.018)\end{array}$ \\
\hline hearings & $\begin{array}{l}-6.696^{\star} \\
(3.654)\end{array}$ & $\begin{array}{l}-6.929^{\star} \\
(3.847)\end{array}$ & $\begin{array}{l}-6.636^{*} \\
(3.906)\end{array}$ & $\begin{array}{l}.543 \\
(.426)\end{array}$ & $\begin{array}{l}.719^{\dagger} \\
(.434)\end{array}$ & $\begin{array}{l}.782^{*} \\
(.438)\end{array}$ \\
\hline GAO investigations & $\begin{array}{l}-3.654 \\
(4.800)\end{array}$ & $\begin{array}{l}-3.800 \\
(4.849)\end{array}$ & $\begin{array}{l}-3.869 \\
(4.847)\end{array}$ & $\begin{array}{l}-.497 \\
(.595)\end{array}$ & $\begin{array}{l}-.421 \\
(.589)\end{array}$ & $\begin{array}{l}-.397 \\
(.588)\end{array}$ \\
\hline independent agency & $\begin{array}{c}175.670 \\
(272.92)\end{array}$ & $\begin{array}{c}183.333 \\
(277.322)\end{array}$ & $\begin{array}{c}183.161 \\
(277.60)\end{array}$ & $\begin{array}{c}12.828 \\
(29.398)\end{array}$ & $\begin{array}{c}4.017 \\
(28.247)\end{array}$ & $\begin{array}{c}5.467 \\
(28.092)\end{array}$ \\
\hline CFR pages & $\begin{array}{l}-.244^{\star \star \star} \\
(.060)\end{array}$ & $\begin{array}{l}-.248^{\star \star \star} \\
(.062)\end{array}$ & $\begin{array}{l}-.245^{\star \star \star} \\
(.063)\end{array}$ & $\begin{array}{l}.002 \\
(.006)\end{array}$ & $\begin{array}{l}.007 \\
(.006)\end{array}$ & $\begin{array}{l}.007 \\
(.005)\end{array}$ \\
\hline budget authority & $\begin{array}{l}.624 \\
(.923)\end{array}$ & $\begin{array}{l}.580 \\
(.940)\end{array}$ & $\begin{array}{l}.580 \\
(.943)\end{array}$ & $\begin{array}{l}.006 \\
(.090)\end{array}$ & $\begin{array}{l}.038 \\
(.086)\end{array}$ & $\begin{array}{l}.046 \\
(.085)\end{array}$ \\
\hline $\begin{array}{l}\text { executive-legislative } \\
\text { conflict }\end{array}$ & & $\begin{array}{l}.300 \\
(.920)\end{array}$ & & & $\begin{array}{l}-.178^{*} \\
(.100)\end{array}$ & \\
\hline unified government & & & $\begin{array}{c}-2.354 \\
(44.107)\end{array}$ & & & $\begin{array}{r}9.647^{*} \\
(4.863)\end{array}$ \\
\hline liberalism score & & $\begin{array}{c}4.658 \\
(15.106)\end{array}$ & $\begin{array}{c}4.088 \\
(15.242)\end{array}$ & & $\begin{array}{l}-3.339^{* *} \\
(1.34)\end{array}$ & $\begin{array}{l}-2.232^{\dagger} \\
(1.468)\end{array}$ \\
\hline constant & $\begin{array}{c}997.73^{* \star *} \\
(97.948)\end{array}$ & $\begin{array}{c}487.931 \\
(643.233)\end{array}$ & $\begin{array}{r}752.952^{\dagger} \\
(496.854)\end{array}$ & $\begin{array}{l}43.745^{* * *} \\
(13.410)\end{array}$ & $\begin{array}{l}375.018^{* * *} \\
(80.166)\end{array}$ & $\begin{array}{l}158.896^{*} \\
(68.977)\end{array}$ \\
\hline prob $>F$ & .0000 & .0000 & .0000 & .0000 & .0000 & .0000 \\
\hline $\mathrm{N}$ & 154 & 154 & 154 & 154 & 154 & 154 \\
\hline
\end{tabular}

Fixed effects regressions with $A R(1)$ disturbances are employed.

Standard errors are in parentheses, ${ }^{\dagger}$ significant at .10 level, ${ }^{*}$ significant at .05 level, ${ }^{* *}$ significant at .01 level, ${ }^{* \star *}$ significant at .001 level (one-tailed).

The statistical results reported table 4 imply that transaction cost might be an important factor affecting participatory governance management, particularly regarding advisory committees. Generally, when transaction cost increases in terms of lobbying, issue salience, and hearings, agencies are less likely to increase advisory committee spending. In contrast, in models 3-2 and 3-3, political environment variables are generally insignificant. It can be concluded that agency decisions in the management of advisory committees are much more dependent on transaction cost than the nature 
of the political environment. In contrast, model 4-1 shows that the effects of transactioncost-related policy conditions are statistically insignificant regarding the frequency of public meetings. Because the effect of public meetings are vulnerable even under lowtransaction-cost policy conditions, it can be concluded that transaction-cost-related policy conditions do not determine whether public meetings are held or not. However, models 4-2 and 4-3 indicate that executive-legislative conflict, the existence of a unified government, and the liberalism score are statistically significant for public meetings. When a conservative public mood prevails or when executive-legislative is insignificant (i.e., limited ideological difference between the president and the median legislator or unified government), agencies are more likely to hold public meetings. These results were opposite of those of advisory committees in models 3-2 and 3-3, implying that the extent to which participatory governance methods are deployed, particularly noninstitutionalized ones, depends on the political environment. ${ }^{7}$

\section{CONCLUSION}

This study examines what role internal and external factors related with transaction cost play in effect of participatory governance on policy performance. Even though participatory governance have been applauded in myriad studies, its effect is not always positive, and agencies never employ its methods unconditionally (Rigg \& O'Mahony, 2013; Robertson \& Choi, 2012). The several regression tests I conducted generally support the basic assumptions of participatory governance; both advisory committees and public meetings have positive effects on policy performance. However, depending on transaction-cost-related policy conditions and the level of institutionalization of participatory governance methods, the effect of participatory governance varies. Basically, the positive effect of participatory governance is limited under high-transactioncost policy conditions. When transaction cost increases, agencies need to spend more time and human resources on the interaction with social policy stakeholders, thereby wasting administrative resources. Thus, even though agencies may be able to secure policy information from social policy stakeholders using participatory governance methods, the effect of participatory governance on policy performance may be negative under high-transaction-cost policy conditions. In addition, the effect is also dependent

7. For statistical robustness, I reexamined the models of public meetings (i.e., models 4-1, 4-2, and 4-3) using by count models such as panel negative binomial regressions and panel Poisson regressions with fixed effects. However, the basic results were similar regarding all four transaction-cost-related policy conditions. 
on the level of institutionalization of participatory governance methods. When participatory governance is institutionalized in policy communities, thereby increasing mutual trust between agencies and social policy stakeholders, the negative effect of transaction cost is more likely to be limited. In other words, the effect of institutionalized participatory governance method tends to be robust even under high-transaction-cost policy conditions. For example, advisory committees are generally maintained for several years, and the relationship between committee members and agency bureaucrats is very close. Institutionalized participatory governance methods enhance mutual trust, which limits the negative effect of transaction cost. In contrast, the effect of public meetings as a noninstitutionalized participatory governance method is highly vulnerable even under low-transaction-cost policy conditions.

These internal and external factors that are related to transaction cost also affect the management of participatory governance methods. Agencies tend to spend more on advisory committees as transaction cost decreases. In contrast, the political environment is less meaningful with respect to advisory committee spending. Because advisory committees tend to be institutionalized in policy communities, the management of the method would be insulated from political environments. On the other hand, transactioncost-related policy conditions are not important when it comes to whether public meetings are held or not. As table 3 indicates, the effect of public meetings can be negative even under low-transaction-cost policy conditions. Thus, agencies have less incentive to consider transaction-cost-related policy conditions in holding public meetings. Rather, when political environments are favorable for agencies, they are more likely to hold public meetings. In other words, regarding the management of public meetings, agencies tend to consider political environments relative to transaction-cost-related policy conditions, partly because of their noninstitutionalization. 
Appendix 1. U.S. Federal Agencies Analyzed

\begin{tabular}{|c|c|c|}
\hline Agency & PART & $\begin{array}{l}\text { Advisory Committee Spending } \\
\text { (2008 dollars) }\end{array}$ \\
\hline Agricultural Marketing Service & 60 & 63294 \\
\hline Alcohol Tobacco Firearms and Explosives Bureau & 68.5 & 0 \\
\hline Animal and Plant Health Inspection Service & 60 & 18338.1 \\
\hline Employment and Training Administration & 64.25 & 167738 \\
\hline Environmental Protection Agency & 60 & 4500000 \\
\hline Farm Service Agency & 76.5 & 0 \\
\hline Federal Aviation Administration & 64.04 & 26593.8 \\
\hline Federal Communications Commission & 58.1 & 532319 \\
\hline Federal Emergency Management Agency & 76.7 & 37275 \\
\hline Federal Highway Administration & 68.5 & 0 \\
\hline Fish and Wildlife Service & 77 & 501425 \\
\hline Food and Drug Administration & 70.5455 & 0 \\
\hline Food and Nutrition Service & 68.5 & 0 \\
\hline Food Safety and Inspection Service & 71.3333 & 0 \\
\hline Forest Service & 66.8 & 460502 \\
\hline Health Care Financing Administration & 72.375 & 241231 \\
\hline Indian Affairs Bureau & 80.875 & 0 \\
\hline Land Management Bureau & 60 & 135561 \\
\hline Mine Safety and Health Administration & 67.2857 & 0 \\
\hline Minerals Management Service & 90.2857 & 195832 \\
\hline National Park Service & 60 & 68416.3 \\
\hline Nuclear Regulatory Commission & 71.3333 & 7266.75 \\
\hline Occupational Safety and Health Administration & 75.15 & 41168.8 \\
\hline Patent and Trademark Office & 87.3333 & 0 \\
\hline Securities and Exchange Commission & 77 & 54500.1 \\
\hline Small Business Administration & 70.2 & 165332 \\
\hline Social Security Administration & 60 & 0 \\
\hline
\end{tabular}

Note: The data are average values for the FY2001-FY2008 period. 


\section{REFERENCES}

Aberbach, J. D. 1990. Keeping a watchful eye: The politics of congressional oversight. Washington DC: The Brookings Institution.

Adams, B. 2004. Public meetings and the democratic process. Public Administration Review, 64(1): 43-54.

Andersson, K., \& van Laerhoven, F. 2007. From local strongman to facilitator: Institutional incentives for participatory municipal governance in Latin America. Comparative Political Studies, 40(9): 1085-1111.

Ansell, C. K. 2011. Pragmatist democracy: Evolutionary learning as public philosophy. New York: Oxford University Press.

Ansell, C. K., \& Gash, A. 2008. Collaborative governance in theory and practice. Journal of Public Administration Research and Theory, 18(4): 543-571.

Applegate, J. S. 1998. Beyond the usual suspects: The use of citizens advisory boards in environmental decisionmaking. Indiana Law Journal, 73(3): 903-957.

Balla, S. J. 2004. Between commenting and negotiation: The contours of public participation in agency rulemaking. I/S: A Journal of Law and Policy for the Information Society, 1(1): 59-94.

Bingham, L. B. 2010. The next generation of administrative law: Building the legal infrastructure for collaborative governance. Wisconsin Law Review, 2010(2): 297-356.

Brewer, G. A., \& Selden, S. C. 2000. Why elephants gallop: Assessing and predicting organizational performance in federal agencies. Journal of Public Administration Research and Theory, 10(4): 685-712.

Brown, T. L., \& Potoski, M. 2003. Transaction costs and institutional explanations for government service production decisions. Journal of Public Administration Research and Theory, 13(4): 441-468.

Cameron, C. M., \& Rosendorff, B. P. 1993. A signaling theory of congressional oversight. Games and Economic Behavior, 5(1): 44-70.

Choi, T. 2014. Revisiting the Relevance of collaborative governance to Korean public administration. Korean Journal of Policy Studies, 29(2): 21-41.

Chubb, J. E., \& Peterson, P. E. 1985. The new direction in American politics. Washington, DC: Brookings Institution Press.

Coglianese, C. 1997. Assessing consensus: The promise and performance of negotiated rulemaking. Duke Law Journal, 46(6): 1255-1349.

Doberstein, C. 2016. Designing collaborative governance decision-making in search of a "collaborative advantage." Public Management Review, 18(6): 819-841.

Dull, M. 2006. Why PART? The institutional politics of presidential budget reform. 
Journal of Public Administration Research and Theory, 16(2): 187-215.

Eom, S.-J., \& Bae, K. 2014. The governance system of industrial policy in the era of growth in Korea from the perspective of state-society relations. Korean Journal of Policy Studies, 29(3): 1-30.

Epstein, D., \& Halloran, S. O. 1999. Delegating powers: A transaction cost politics approach to policy making under separate powers. New York: Cambridge University Press.

Freeman, J. 1997. Collaborative governance in the administrative state. UCLA Law Review, 1(1): 1-98.

Frieling, M. A., Lindenberg, S. M., \& Stokman, F. N. 2014. Collaborative Communities through coproduction: Two case studies. American Review of Public Administration, 44(1): 35-58.

Gallo, N., \& D. E. Lewis. 2012. The consequences of presidential patronage for federal agency performance. Journal of Public Administration Research and Theory, 22(2): 219-243.

Gerlak, A. K., Heikkila, T., \& Lubell, M. 2012. The promise and performance of collaborative governance. In S. Kamieniecki and M. E. Kraft (eds.), The Oxford handbook of U.S. environmental policy (pp. 413-434). New York: Oxford University Press.

Gormley, W. T. 1986. Regulatory issue networks in a federal system. Polity, 18(4): 595-620.

Gormley, W. T., \& Balla, S. J. 2004. Bureaucracy and democracy: Accountability and performance. Washington DC: CQ Press.

Gunningham, N. 2009. The new collaborative environmental governance: The localization of regulation. Journal of Law and Society, 36(1): 145-166.

Haider-Markel, D. P., \& K. J. Meier. 1996. The politics of gay and lesbian rights: Expanding the scope of the conflict. Journal of Politics, 58(2): 332-349.

Harmon, M. M. 1995. Responsibility as paradox: A critique of rational discourse on government. Thousand Oaks, CA: Sage.

Harter, P. 1982. Negotiating regulations: A cure for the malaise. Georgetown Law Journal, 71(1): 1-118.

Imperial, M. T. 2005. Using collaboration as a governance strategy: Lessons from six watershed management programs. Administration and Society, 37(3): 281-320.

Innes, J. E., \& Booher, D. E. 1999. Consensus building and complex adaptive systems. Journal of the American Planning Association, 65(4): 412-423.

John, G., \& Weitz, B.A. 1988. Forward integration into distribution: An empirical test of transaction cost analysis. Journal of Law, Economics, and Organization, 4(2): 337-355. 
Jones, B. D., Thomas, H. F., \& Wolfe, M. 2014. Policy bubbles. Policy Studies Journal, 42(1): 146-171.

Kelly, T. 2004. Unlocking the iron cage: Public administration in the deliberative democratic theory of Jürgen Habermas. Administration and Society, 36(1): 38-61.

Langbein, L. I., \& Kerwin, C. M. 2000. Regulatory negotiation versus conventional rule making: Claims, counterclaims, and empirical evidence. Journal of Public Administration Research and Theory, 10(3): 599-632.

Leach, W. D. 2006. Collaborative public management and democracy: Evidence from western watershed partnerships. Public Administration Review, 66(s1): 100-110.

Lee, J. 2013. The administrative broker: Bureaucratic politics in the era of prevalent information. American Review of Public Administration, 43(6): 690-708.

Lubbers, J. S. 2008. Achieving policymaking consensus: The (unfortunate) waning of negotiated rulemaking. South Texas Law Review, 49(4): 987-1017.

Marcus, A. A., Geffen, D. A., \& K. Sexton. 2002. Reinventing environmental regulation: Lessons from Project XL. Washington DC: RFF Press.

McCann, L., Colby, B, Easter, K. W., Kasterine, A., \& Kuperan, K. V. 2005. Transaction cost measurement for evaluating environmental policies. Ecological Economics, 52(4): 527-542.

McComas, K. A. 2001. Public meetings about local waste management problems: Comparing participants to nonparticipants. Environmental Management, 27(1): 135-147.

Mee, S. 1997. Negotiated rulemaking and combined sewer overflows (CSOs): Consensus saves ossification? Boston College Environmental Affairs Law Review, 25(1): 213-245.

Meier, K. J., \& O'Toole, L. J. 2013. Subjective organizational performance and measurement error: Common source bias and spurious relationships. Journal of Public Administration Research and Theory, 23(2): 429-456.

Moe, T. M. 1990. The politics of structural choice: Toward a theory of public bureaucracy. In O. E. Williamson (ed.), Organization theory: From Chester Barnard to the present and beyond (pp. 116-153). New York: Oxford University Press.

Moynihan, D. P. 2013. Advancing the empirical Study of performance management: What we learned from the program assessment rating tool. American Review of Public Administration, 43(5): 499-517.

Neshkova, M. I., \& Guo, H. 2012. Public participation and organizational performance: Evidence from state agencies. Journal of Public Administration Research and Theory, 22(2): 267-288.

Nicholson-Crotty, S., \& O'Toole, L. J. 2004. Public management and organizational performance: The case of law enforcement agencies. Journal of Public Adminis- 
tration Research and Theory, 14(1): 1-18.

Osborne, M. J., Rosenthal, J. S., \& M. A. Turner. 2000. Meetings with costly participation. American Economic Review, 90(4): 927-943.

Paletta, A. 2012. Public governance and school performance. Public Management Review, 14(8): 1125-1151.

Paulson, K. A. 2004. Regulation through intimidation: Congressional hearings and political pressure on America's entertainment media. Vanderbilt Journal of Entertainment Law and Practice, 7(1): 61-86.

Pizzo, M. 2013. Related party transactions under a contingency perspective. Journal of Management and Governance, 17(2): 309-330.

Rangan, V. K., Corey, E. R., \& Cespedes, F. 1993. Transaction cost theory: Inferences from clinical field research on downstream vertical integration. Organization Science, 4(3): 454-477.

Reeves, E. 2008. The practice of contracting in public private partnerships: Transaction costs and relational contracting in the Irish schools sector. Public Administration, 86(4): 969-986.

Rigg, C., \& O’Mahony, N. 2013. Frustrations in collaborative working. Public Management Review, 15(1): 83-108.

Roberts, N. C. 2002. Keeping public officials accountable through dialogue: Resolving the accountability paradox. Public Administration Review, 62(6): 658-669.

Robertson, P. J., \& Choi, T. 2012. Deliberation, consensus, and stakeholder satisfaction. Public Management Review, 14(1): 83-103.

Shapiro, S. 2007. The role of procedural controls in OSHA's ergonomics rulemaking. Public Administration Review, 67(4): 688-701.

Singleton, S. 2002. Collaborative environmental planning in the American West: The good, the bad and the ugly. Environmental Politics, 11(3): 54-75.

Sousa, D. J., \& Klyza, C. M. 2007. New directions in environmental policy making: An emerging collaborative regime or reinventing interest group liberalism? Natural Resources Journal, 47(1): 377-444.

Susskind, L., \& McMahon, G. 1985. The theory and practice of negotiated rulemaking. Yale Journal on Regulation, 3(1): 133-165.

Wang, X., \& Wart, M. W. 2007. When public participation in administration leads to trust: An empirical assessment of managers' perceptions. Public Administration Review, 67(2): 265-278.

Warner, J. F. 2006. More sustainable participation? Multi-stakeholder platforms for integrated catchment management. International Journal of Water Resources Development, 22(1): 15-35.

Willem, A., \& Lucidarme, S. 2014. Pitfalls and challenges for trust and effectiveness 
in collaborative networks. Public Management Review, 16(5): 733-760.

Williamson, O. E. 1985. The Economic institutions of capitalism. Oxford: Oxford University Press.

Williamson, O. E. 1991. Comparative economic organization: The analysis of discrete structural alternatives. Administrative Science Quarterly, 36(2): 269-296.

Williamson, O. E. 1996. The mechanisms of governance. New York: Oxford University Press.

Wolfe, M. 2012. Putting on the brakes or pressing on the gas? Media attention and the speed of policymaking. Policy Studies Journal, 40(1): 109-126.

Wondolleck, J. M., \& S. L. Yaffee. 2000. Making collaboration work: Lessons from innovation in natural resource management. Washington, DC: Island Press. 